PNL-6973

UC-11,41

$\therefore C$

\title{
The Installation of the Westbay Multiport Ground-Water Sampling System in Well 699-43-42K Near the 216-B-3 Pond
}

T. J. Gilmore

September 1989

Prepared for the U.S. Department of Energy under Contract DE-AC06-76RLO 1830

Pacific Northwest Laboratory

Operated for the U.S. Department of Energy by Battelle Memorial Institute 


\title{
DISCLAJMER
}

This program was prepared as an account of work sponsored by an agency of the United States Government. Neither the United States Government nor any agency thereof, nor Battelle Memorial Institute, nor any or their employees, makes any warranty, expressed or implied, or assumes any legal liability or responsibility for the accuracy, completeness, or usefulness of any information, apparatus, product, or process disclosed, or represents that its use would not infringe privately owned rights. Reference herein to any specific commercial product, process, or service by trade name, trademark, manufacturer, or otherwise, does not necessarily constitute or imply its endorsement, recommendation, or favoring by the United States Government of any agency thereof, or Battelle Memorial Institute. The views and opinions of authors expressed herein do not necessarily state or reflect those of the United States Government or any agency thereof.

\author{
PACIFIC NORTHWEST LABORATORY \\ operated by \\ BATTELLE MEMORIAL INSTITUTE \\ for the \\ UNITED STATES DEPARTMENT OF ENERGY \\ under Contract DE-ACO6-76RLO 1830
}

Printed in the United States of America

Available to DOE and DOE contractors from the

Office of Scientific and Technical Information, P.O. Box 62, Oak Ridge, TN 37831; prices avaiłable from (615) 576-840?. FTS 626-8401.

Available to the public from the National Technical Information Service, U.S. Department of Commerce, 5285 Port Royal Rd., Springfield, VA 22161.

NTIS Price Codes, Microfiche A0T

Printed Copy

\begin{tabular}{|c|c|}
\hline Pages & $\begin{array}{l}\text { Price } \\
\text { Codes }\end{array}$ \\
\hline$\overline{001-025}$ & $\overline{\mathrm{A} 02}$ \\
\hline $026-050$ & $\mathrm{~A} 03$ \\
\hline $051-075$ & $\mathrm{~A} 04$ \\
\hline $076-100$ & A05 \\
\hline $101-125$ & $\mathrm{~A} 06$ \\
\hline $126-150$ & $\mathrm{~A} 07$ \\
\hline $151-175$ & $A 0 B$ \\
\hline $176-200$ & $\mathrm{~A} 09$ \\
\hline $201-225$ & A 10 \\
\hline $226-250$ & A11 \\
\hline 251.275 & A12 \\
\hline $276-300$ & A 13 \\
\hline
\end{tabular}


T. J. Gilmore

September 1989

Prepared for the U.S. Department of Energy under Contract DE-AC06-76RLO 1830

Pacific Northwest Laboratory Richland, Washington 99352 


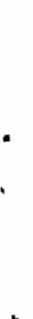




\section{SUMMARY}

In 1988 and 1989, Pacific Northwest Laboratory installed a multiport ground-water sampling system in well 699-43-42K drilled near the 216-B-3 Pond on the Hanford Site in southeastern Washington State. The multiport system will be used to evaluate methods for determining the vertical distribution of contaminants and hydraulic heads in ground water. This installation was in conjunction with a similar multiport installation near the 300 Area of the Hanford Site. Well 699-43-42K is adjacent to two Resource Conservation and Recovery Act (RCRA) ground-water monitoring wells, which will allow for a comparison of sampling intervals and head measurements between the multiport system and the RCRA monitoring weils.

Eight sampling ports were installed in the upper unconfined aquifer by backfilling at depths of $161.1 \mathrm{ft}, 174.1 \mathrm{ft}, 187.1 \mathrm{ft}, 201.17 \mathrm{ft}, 217.2 \mathrm{ft}$, $230.2 \mathrm{ft}, 243.2 \mathrm{ft}$, and $255.2 \mathrm{ft}$ below $\mathrm{T}$ and surface. However, because of damage to the casing during installation, only the top four ports should be used for pressure measurements and sampling until repairs occur. The locations of the sampling ports were determined by the hydrogeology of the area and the screened intervals of adjacent ground-water monjtoring wells.

Installation by backfilling around the multiport system was the first method of its kind on the Hanford Site and proved adequate. For future installations, an alternative method is recommended where the multiport system would be placed inside a cased and screened well using packers to isolate the sampling zones. 
. 


\section{CONTENTS}

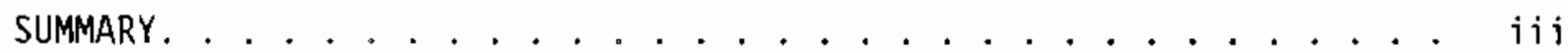

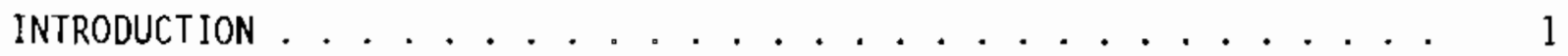

GEOLOGY ........................... 5

GEOPHYSICAL LOGGING ................ 6

DRILLING AND INSTALLATION ....................... 7

DRILLING OPERATIONS ...................... 7

INSTALLATION . . . . . . . . . . . . . . . . . . 7

Backfill Material ................... 9

Usable Sampling Ports ............... 12

WELL DEVELOPMENT . . . . . . . . . . . . . . . . . . 14

CONCLUSION AND RECOMMENDATIONS .................... 15

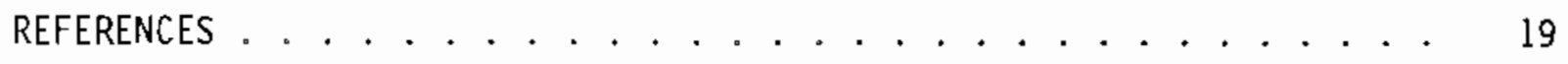

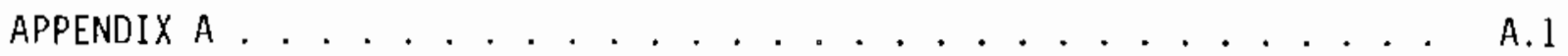




\section{FIGURES}

1 Hanford Site Location Map ................ 2

2 Location of 699-43-42K Near the 216-B-3 Pond on the Hanford Site ................. 3

3 Diagram of Multiport System and Adjacent Resource Conservation and Recovery Act Monitoring Wells ........... 4

4 Well 699-43-42K Construction Progress Curve . . . . . . . . . 8

5 Completion Arrangement at the Well Head . . . . . . . . . 10

6 Multiport Monitoring Zone Configuration . . . . . . . . . 11

7 Pressure Transducer Readings . . . . . . . . . . . . . 13

8 Installation of Multiport System in a Cased and Screened Wel1 a) placing 4-in. stainless-steel casing in well; b) backfilling around 4-in. stainless-steel casing; c) placing multiport system

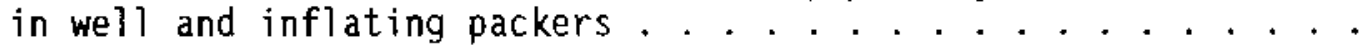




\section{INTRODUCTION}

A Westbay multiport ground-water sampling system was installed in a wel1 on the Hanford Site as part of Pacific Northwest Laboratory's

(PNL's) (a) Site-Wide Ground-Water Monitoring Project. The installation of the multiport system is part of a program to evaluate methods that determine the vertical distribution of contaminants and hydraulic head in the ground water. Two multiport systems were installed during the last quarter of 1988 and the first quarter of 1989. This report discusses the installation and completion of the multiport system in well 699-43-42K near the 216-B-3 Pond on the Hanford Site. A similar report discusses the installation of a multiport system in well 399-1-20 near the 300 Area on the Hanford Site (Gilmore 1989).

The drilling of well 699-43-42K for the multiport system was completed in January 1989 by Onwego Drilling Company, Richland, Washington, under subcontract to PNL. Pacific Northwest Laboratory furnished contract management and supervised the drilling and installation of the multiport system. Geological data were gathered by PNL personnel. Under contract to PNL, Westbay Instruments Ltd. provided initial consultation on the assembly and installation of the system.

We11 699-43-42K is located in southeastern Washington State on the Hanford Site (Figures 1 and 2). Coordinates for well 699-43-42K are N136,445.2 E576,997.5 meters NAD83 (North American Datum of 1983). The well was drilled to a total depth of $263.0 \mathrm{ft}$ and was completed to $261.87 \mathrm{ft}$. The multiport system was installed immediately adjacent to two Resource Conservation and Recovery Act (RCRA) ground-water monitoring wells, 699-42-42B and 699-43-42J (Figure 2). Well 699-42-42B was completed to $250 \mathrm{ft}$, and well 699-43-42J was completed to $180 \mathrm{ft}$ (Figure 3). This location will provide a comparison of sampling intervals between the multiport system and the RCRA monitoring wells.

(a) Pacific Northwest Laboratory is operated for the U.S. Department of Energy by Battelle Memorial Institute under Contract DE-AC06-76RLO, 1830 . 


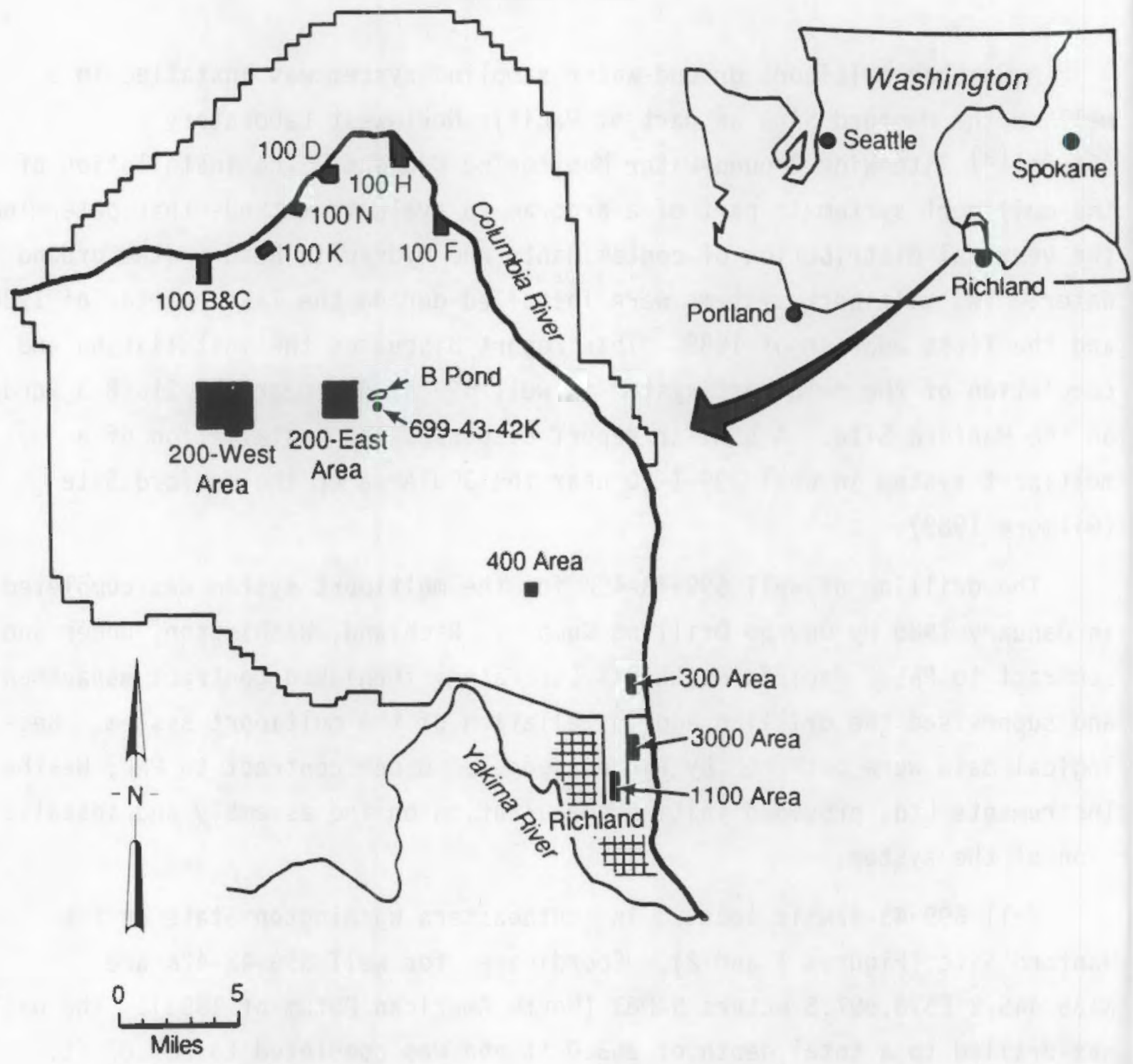

-Well Location

FIGURE 1. Hanford Site Location Map

Appendix A contains the as-built diagrams with a geologic column, geophysical logs, the completion/inspection reports; the casing record sheets for well 699-43-42K; and the gamma log with the lithology and port intervals. 


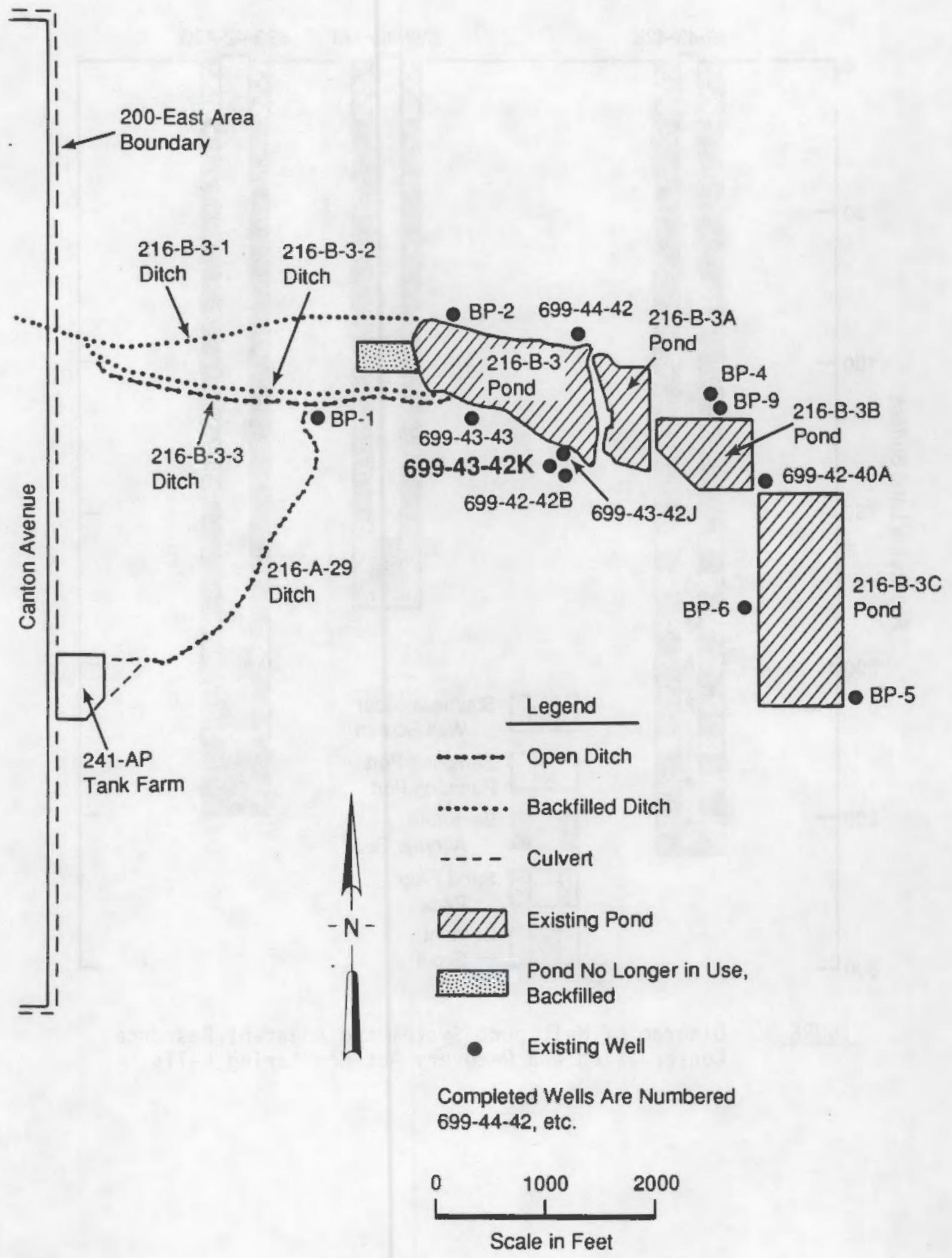

FIGURE 2. Location of 699-43-42K Near the 216-B-3 Pond on the Hanford Site 


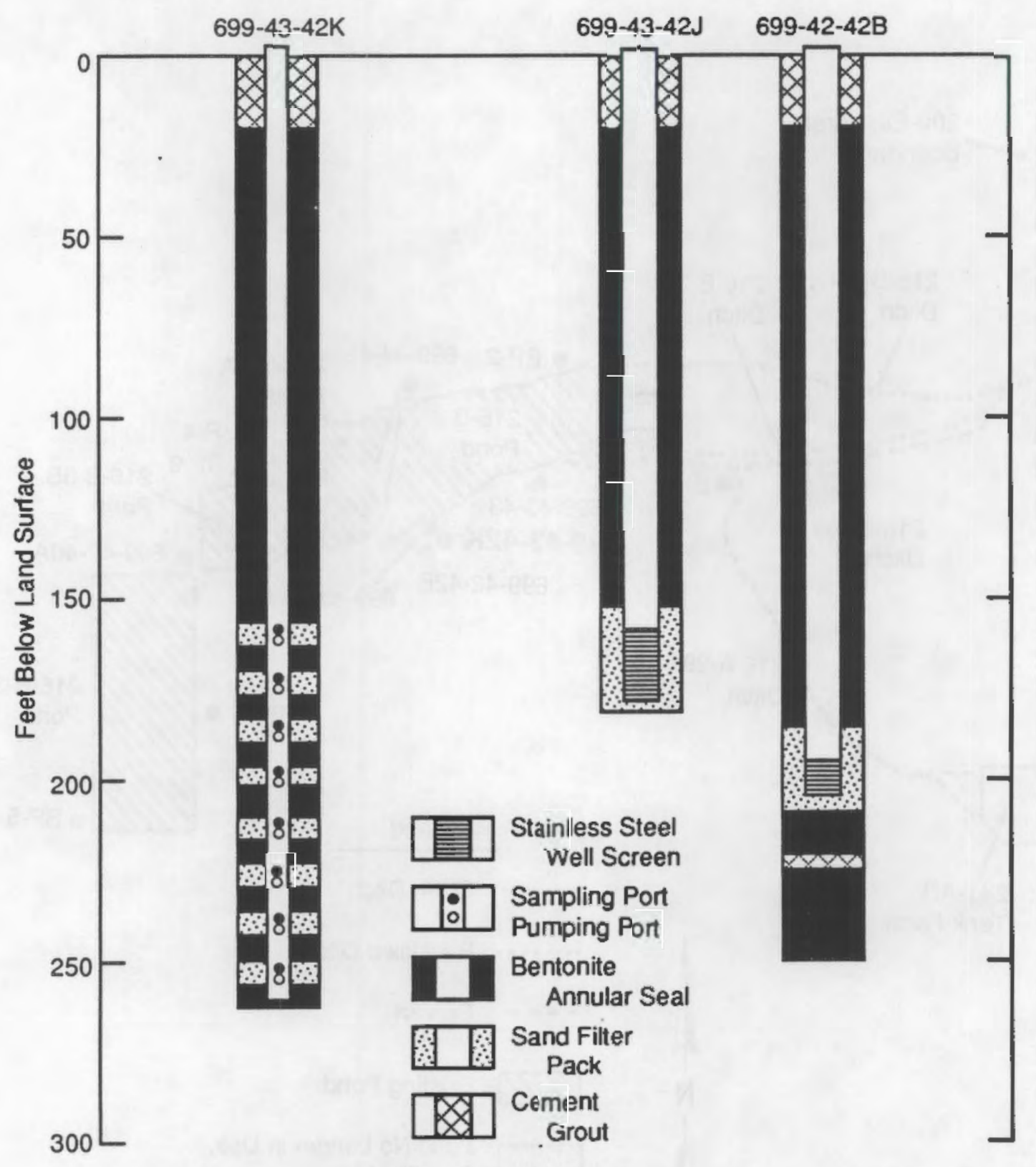

FIGURE 3. Diagram of Multiport System and Adjacent Resource Conservation and Recovery Act Monitoring Wells 


\section{GEOLOGY}

The stratigraphy in well 699-43-42K closely correlates with that in the adjacent RCRA monitoring wells. Three major stratigraphic formations were encountered during drilling, which include in ascending order the Columbia Basalt Group, the Ringold Formation, and the glacial-fluvial sediments.

The top of the basalt occurs at $243 \mathrm{ft}$ and is present at the final depth of $263 \mathrm{ft}$ below ground surface in well 699-43-42K. The top of the basalt is likely the erosional remnants of the Elephant Mountain Member (Graham, Last, and Fecht 1984). The basalt is very dark grayish brown, amygdaloid, with some oxidized coatings. The amygdules are commonly filled with silicious, white opaline-type material. Between 260 and $258 \mathrm{ft}$, a zone of relatively easier drilling occurs. The sample descriptions describe this zone as gravely silty-sand composed predominantly of basalt grains. The natural gamma log supports this description and indicates the zone to be coarser grained then the surrounding basalt signature. This zone is possibly an epiblastic interbed or a weathered zone in or between basalt flows.

The Ringold Formation has been identified in the region by Graham, Last, and Fecht (1984) and Tallman et al. (1979), and extends from approximately 243 to $111 \mathrm{ft}$ below the ground surface. The basal, lower, and middle Ringold units are suggested to be present in the region of well 699-43-42K (Graham, Last, and Fecht 1984); however, the correlation of these units to this well requires more characterization work. The Ringold Formation in this discussion is treated as undifferentiated, with the notable lithologic changes discussed. The Ringold Formation is generaliy characterized by gravels and sands in a silty matrix. There was an increase in the silt and gravel contents over the Hanford formation, but no noticeable increase or decrease in the percentage of basalt grains. Two notable units of clayey silt exist in the well. These occur at 233 to $204 \mathrm{ft}$ and 181 to $150 \mathrm{ft}$ below the ground surface. The layers of clayey silt are bracketed by sandy gravels.

The upper giacial-fluvial sediments informally termed the Hanford formation extend from $111 \mathrm{ft}$ to near the surface. The sediments between $111 \mathrm{ft}$ 
and $17 \mathrm{ft}$ are composed of unconsolidated well-sorted, medium to fine sands. Thin layers of silt approximately $1 \mathrm{ft}$ thick occur at $97 \mathrm{ft}$ and $93 \mathrm{ft}$. The sediments are composed of gravelly sand from $17 \mathrm{ft}$ to the surface. Geology logs are presented in Appendix A.

\section{GEOPHYSICAL LOGGING}

Pacific Northwest Laboratory logged well 699-43-42K using density, natural gamma, and neutron probes on November 18, 1989. The well was logged between $0 \mathrm{ft}$ and $263 \mathrm{ft}$. The natural gamma logs were used to verify silt/clay layers and interbeds in the decisions to locate sampling ports (Appendix A). 


\section{DRILLING AND INSTALLATION}

\section{DRILLING OPERATIONS}

We11 699-43-42K was drilled using a Bucyrus Erie 22-W cable tool drilling rig by the drive barrel and hard-tool method. Drilling operations began on September 29, 1988, and continued to November 16, 1988, totaling 36 days of drilling (Figure 4). The total depth of the well was $263 \mathrm{ft}$. A drive barrel was used to drill between $0 \mathrm{ft}$ and $111 \mathrm{ft}$, and a hard tool was used between 111 and $236 \mathrm{ft}$. Temporary telescoping carbon steel 12-in. casing was placed from the surface to $116.5 \mathrm{ft}$, and $10-\mathrm{in}$. temporary casing was placed from the surface to the total depth of $258.5 \mathrm{ft}$. During construction, the 10 -in. casing was removed twice, once at $116 \mathrm{ft}$ to replace bent casing and once at $207 \mathrm{ft}$ to replace a lost drive shoe. The drive shoe was not recovered and was pushed into the well sidewall at approximately $206 \mathrm{ft}$.

\section{INSTALLATION}

Prior to the installation of the multiport system, sampling intervals were determined based on the hydrogeology of the borehole and the screened intervals of adjacent monitoring wells. The natural gamma geophysical logs and geology logs were used to locate these sampling intervals. The required multiport casing lengths for the chosen sampling intervals were calculated and the pieces laid out in order. Each casing length was given a number sequentially from the bottom of the monitoring well, and an appropriate coupling was attached to the top of each casing. All casing lengths were measured and recorded (see Appendix A). The multiport components were protected by plastic shipping covers until installation. Casing lengths were $10 \mathrm{ft}$ and under in length in divisions of $5 \mathrm{ft}, 2 \mathrm{ft}$, and $1 \mathrm{ft}$. The multiport system was constructed of 1.5-in.-inside-diameter polyvinylchloride (PVC) pipe with well screens that measured $2.88 \mathrm{in}$. outside diameter. The multiport system was then placed in the well inside a 4 -in. schedule 80 PVC protective casing. This casing was used to protect the multiport system and keep the screens free of seal material. A centralizer was placed $10 \mathrm{ft}$ from the bottom of the protective casing to center the multiport system in the well. As the multiport system was placed in the well, each assembled joint 


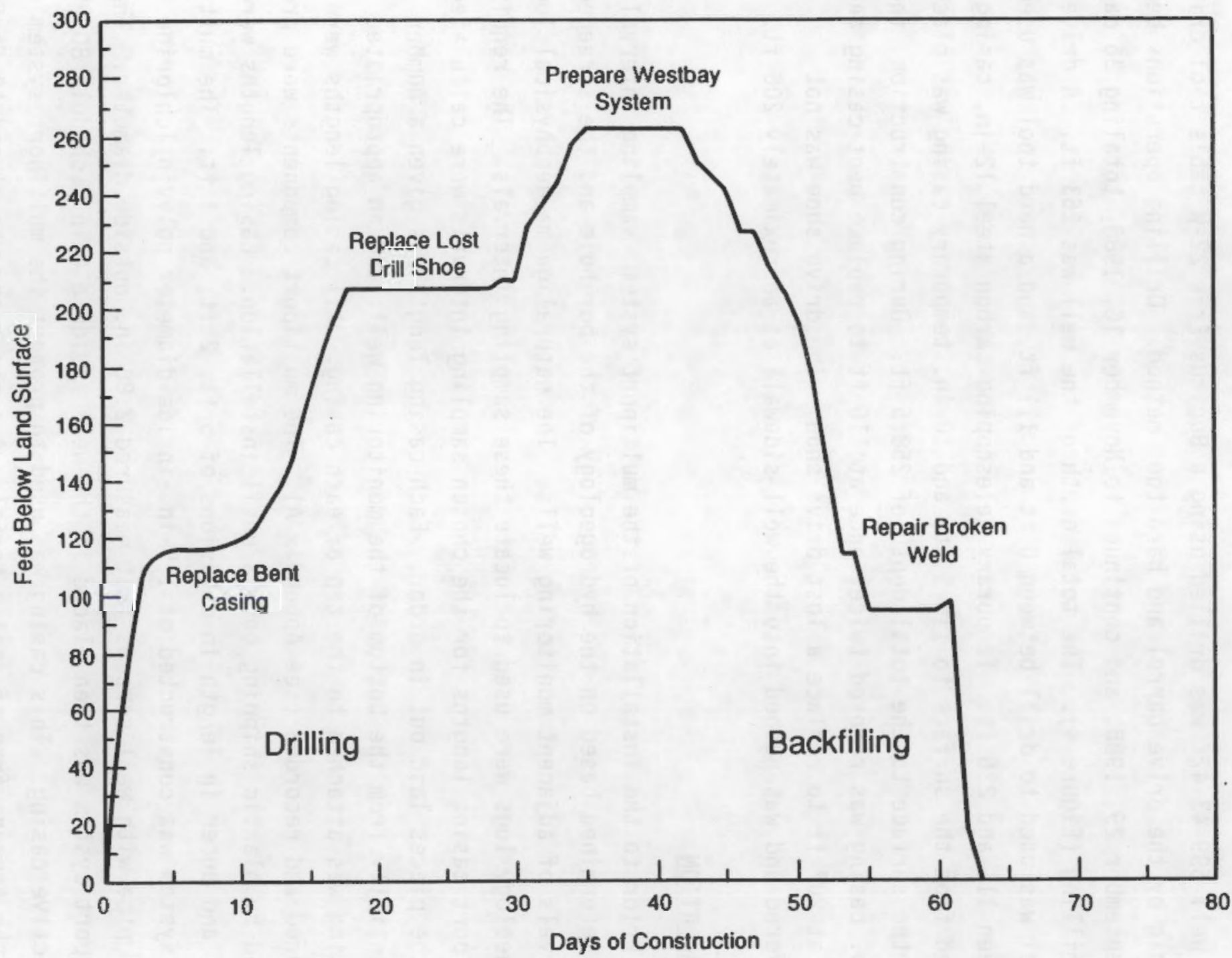

FIGURE 4. Well 699-43-43K Construction Progress Curve 
was hydraulically tested by applying a minimum internal pressure of 100 psi. After the multiport system was properly positioned and secured, the system was backfilled.

The temporary carbon steel casing was removed during the backfilling using hydraulic jacks (Figure 5), which proved much easier than using the cable-tool rig to remove the casing (Gilmore 1989). A minimum l-ft overlap was maintained between the carbon steel casing and the backfill material. A longer overlap was employed when placing the sand filter pack, and a shorter overlap was required when placing the bentonite to reduce "hitching" of the clay on the end of the casing. When the temporary carbon steel casing is cut with an acetylene cutting torch, the protective casing around the multiport system must be shielded from the heat. A 4-in. steel pipe with an adaptive collar to screw into a 4-in. PVC pipe was used over the multiport system to protect the system from the heat.

\section{Backfill Material}

A minimum of $10-i n$. casing was required to accommodate working room for the tremie pipe and protective casing around the multiport system for the placement of the annular filter packs and seals. Eight sampling ports were placed at $161.1 \mathrm{ft}, 174.1 \mathrm{ft}, 187.1 \mathrm{ft}, 201.17 \mathrm{ft}, 217.2 \mathrm{ft}, 230.2 \mathrm{ft}$, $243.2 \mathrm{ft}$, and $255.2 \mathrm{ft}$ below land surface. Backfill around the sampling ports was 20-40 Colorado Silica Sand emplaced by gravity feed. Each sampling port has approximately $2.5 \mathrm{ft}$ of sand filter pack above it and $4.5 \mathrm{ft}$ of filter sand pack below it for a total sampling interval of approximately $7 \mathrm{ft}$ (Figure 6). Medium-size Enviroplug bentonite chunks were placed by gravity feed between the filter sand packs isolating each sampling interval. The medium-size Enviroplug is composed of irregularly shaped bentonite pieces that range in size from $1 / 4$ to $1 \mathrm{in.}$. Prior to placing the bentonite in the well, it was sieved over a coarse mesh screen to remove the fines in order to reduce bridging in the well. The bentonite was then poured through a funnel into a 4-in. PVC tremie pipe for placement in the well. The funnel was used to control the speed of the placement of the bentonite to approximately $2.51 \mathrm{~b} / \mathrm{min}$, because bridging would occur at higher rates. The minimum thickness of the bentonite seals was $5.9 \mathrm{ft}$ between ports 3 and 4 . 


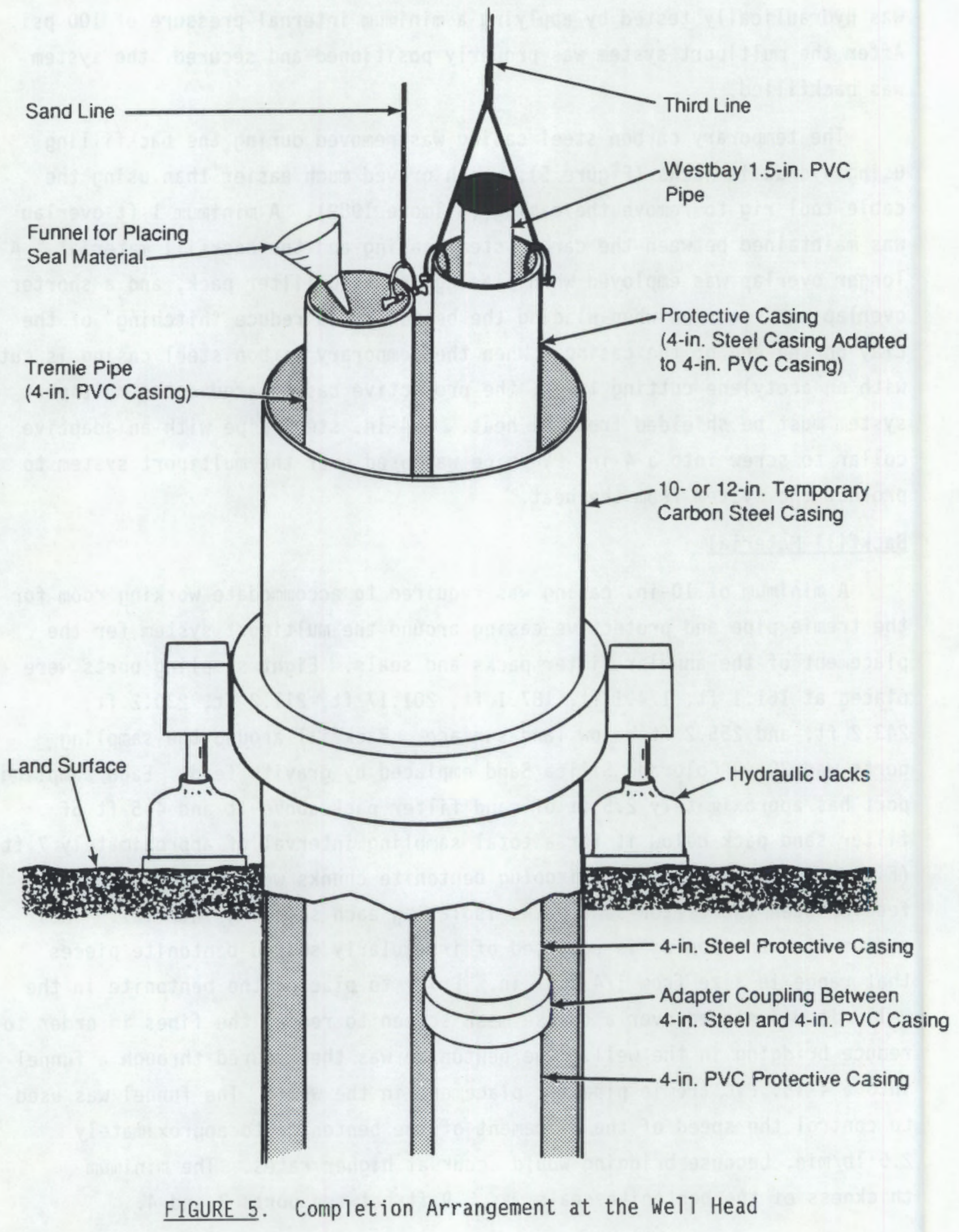




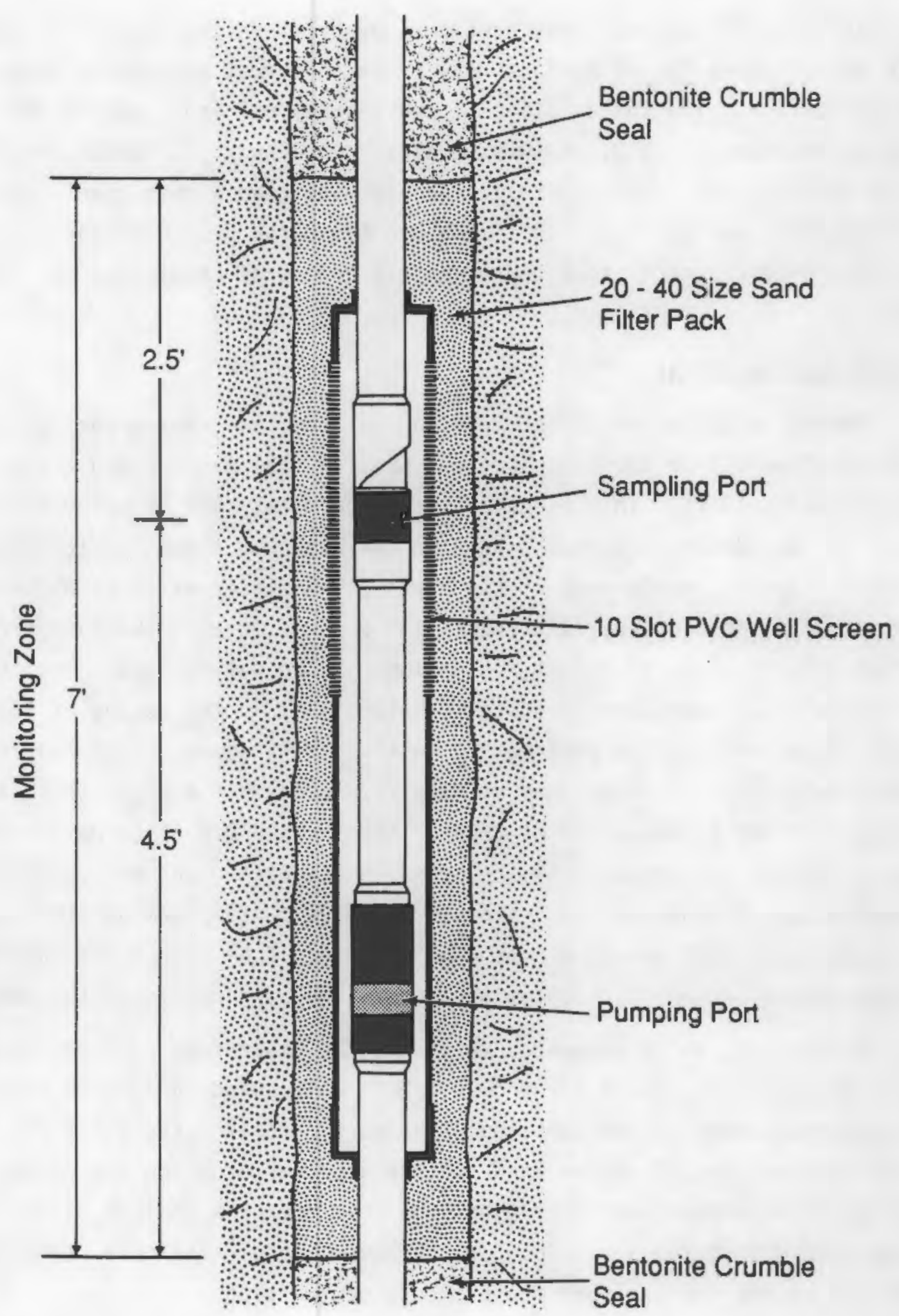

FIGURE 6. Multiport Monitoring Zone Configuration 
The integrity of the seals was confirmed by pressure transducer readings at each port (Figure 7). A surface seal of cement grout was placed from $20 \mathrm{ft}$ to the surface. The installation of the Westbay multiport system was initiated on December 8, 1988, and was completed on January 12, 1989, for a total of 23 working days. This installation time included 6 days spent retrieving and rewelding the $10-\mathrm{ft}$ casing that broke below the ground surface. Excluding this repair time it took approximately 2 days of completion per sampling port.

\section{Usable Sampling Ports}

During installation of the multiport system, the casing was damaged when the tremie pipe used to place the annular seal was dropped and fell approximately $15 \mathrm{ft}$. This occurred at approximately $220 \mathrm{ft}$ below land surface. It was determined that a hole in the casing was open to formational water during the development of the ports. The static water level inside the casing during development returned to $162.5 \mathrm{ft}$ after each evacuation of the casing. The casing, if intact, is designed to be water tight. The location of the hole was indicated by a static water level in the casing of $162.5 \mathrm{ft}$, which is the same as the piezometric level that has been calculated for approximately $219 \mathrm{ft}$ below land surface. In addition, a tight spot in the casing will not allow a tool of greater length than $0.8 \mathrm{ft}$ to pass below the $219 \mathrm{ft}$ level. Confirmation of the break in the casing was attempted using a downhole camera; however, the water in the multiport system at $219 \mathrm{ft}$ was murky and the exact nature of the damage could not be seen. The casing does not provide a pathway for contaminant migration as a result of the damage.

At present, it is suggested that only the upper four ports at depths of $161.1 \mathrm{ft}, 174.1 \mathrm{ft}, 187.1 \mathrm{ft}$, and $201.17 \mathrm{ft}$ below land surface be used for pressure measurements and sampling. The ports at $217.2 \mathrm{ft}, 230.2 \mathrm{ft}$, $243.2 \mathrm{ft}$, and $255.2 \mathrm{ft}$ below land surface are near or below the damage in the casing. The damage should first be repaired, and/or a smaller sized sampler (less than $0.8 \mathrm{ft}$ long) be used for the lower ports. The hole in the casing will not affect the pressure measurements or sampling. 


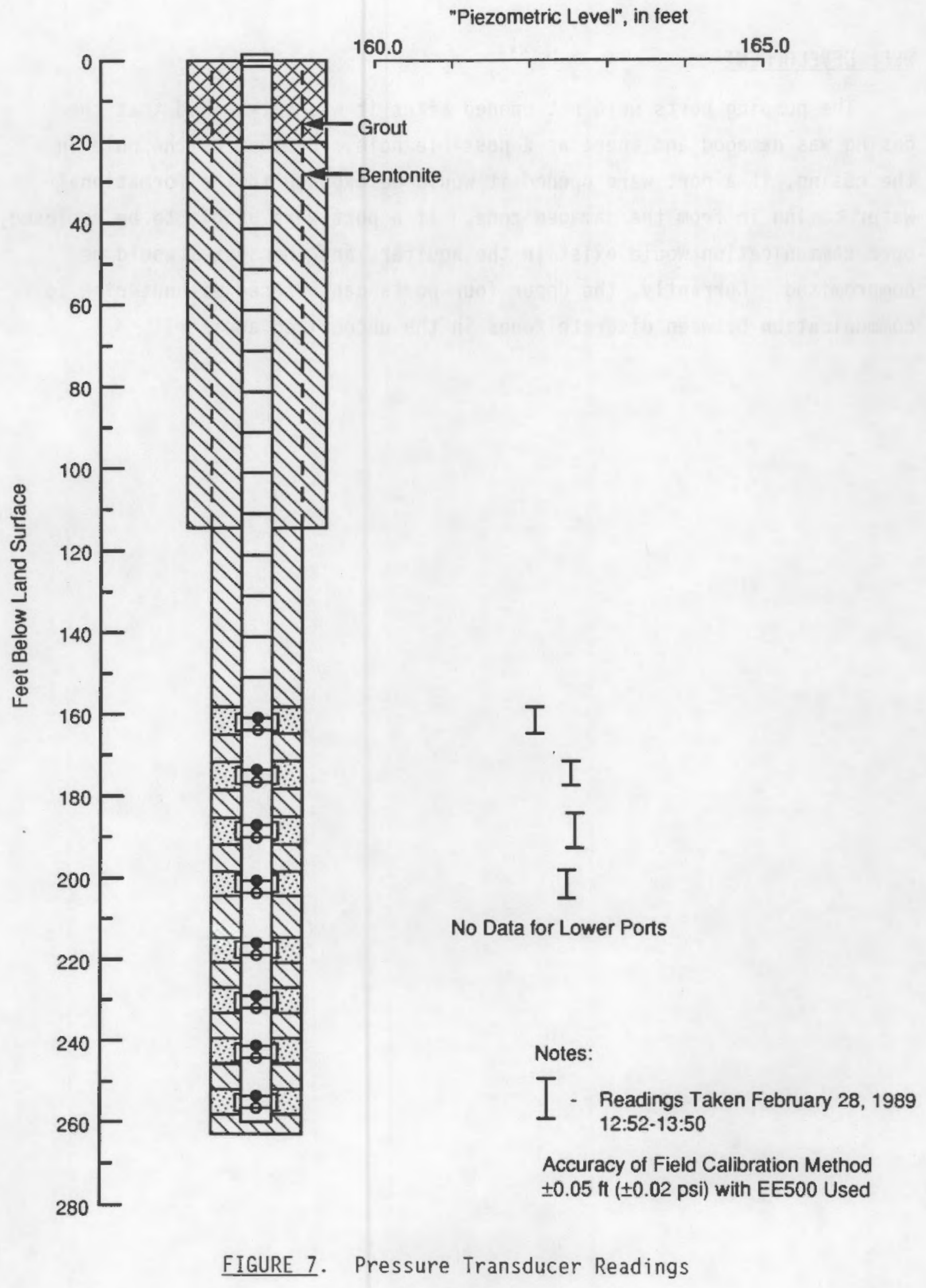




\section{WELL DEVELOPMENT}

The pumping ports were not opened after it was determined that the casing was damaged and there as a possible hole. Because of the hole in the casing, if a port were opened it would be exposed to the formational water coming in from the damaged zone. If a port were unable to be reclosed, open communication would exist in the aquifer, and the system would be compromised. Currently, the upper four ports can be used without risk to communication between discrete zones in the unconfined aquifer. 


\section{CONCLUSIONS AND RECOMMENDATIONS}

The Westbay system is a versatile multiport system that provides data on vertical contamination and hydraulic head distribution representative of formation conditions from a single well. The system's major advantage is its modular design, allowing versatile monitoring configurations that can be easily customized to any location and installed in a single well. Another advantage is that the samples and pressure measurements are taken outside the access tube through the sampling port. This eliminates the need to purge the access tube during sampling; therefore, the sample's fluid chemistry is not altered as a result of degassing, oxidation, biogenic activity, and precipitation. The lag time on fluid pressure measurements is also reduced relative to a conventional standpipe well. Additionally, the multiport system allows the integrity of coupling valves, joints, and the annulus seals to be verified during installation and operation.

A major disadvantage is that the operation of the system is labor intensive and requires substantial training. The installation of the system in a backfilling operation is also more difficult than conventional standpipe well construction because the multiple screened intervals and the PVC construction require additional protection during backfilling. Very little maintenance can be performed after the system is installed by backfilling; therefore, should the system components fail, the life span of the system would be curtailed.

Studies on obtaining representative samples without purging the system are recommended prior to installing more multiport systems. Results from these studies could have an impact on installation methods. One method that is recommended for technical review is the installation of the system in a specially cased and screened well. This method would allow the removal and repair of the system after installation and would reduce the possibility of damage to the multiport system during well completion. Stainless steel 4-in. casing, screened at desired monitoring locations, would be placed in 
the well and backfilled. The multiport system would be placed inside this 4-in. stainless steel casing, using packers to isolate sampling intervals (Figure 8). According to Frank Patton, President and owner of Westbay Instruments Inc., a similar installation technique has been used successfully by the Orange County Water District, California. 


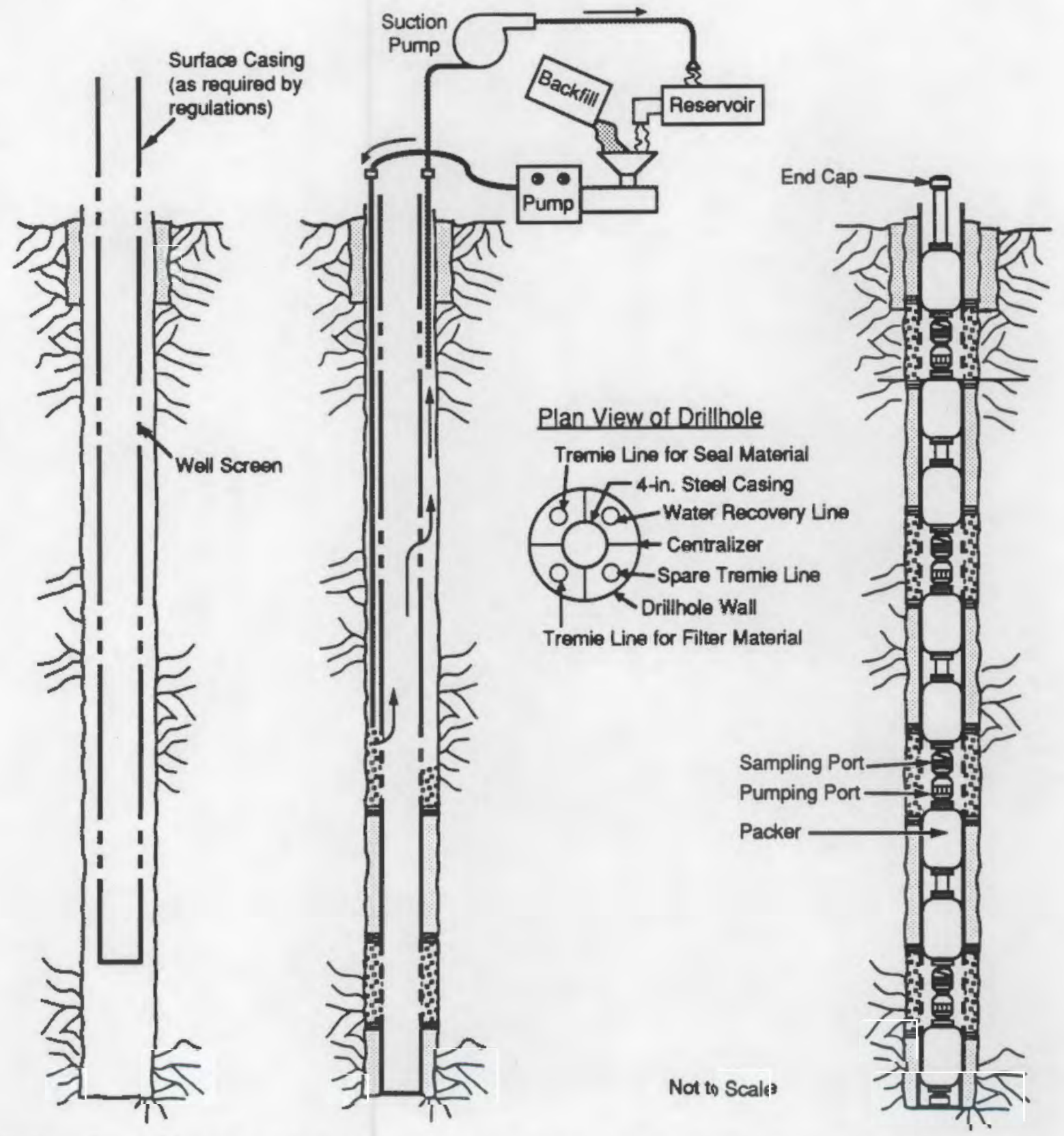

FIGURE 8. Installation of Multiport System in a Cased and Screened Well a) placing 4-in. stainless-steel casing in well; b) back filling around $4-i n$. stainless-steel casing; c) placing multiport system in well and inflating packers (after drawings provided by Westbay Instruments Inc.) 



\section{REFERENCES}

Black, W. H., H. R. Smith, and F. D. Patton. 1986. "Multiple-Level GroundWater Monitoring with the MP system." Paper presented at the Surface and Bore Hole Geophysical Methods and Ground Water Instrumentation Conference and Exposition, October 1986, Denver, Colorado.

Gilmore, T. J. 1989. The Installation of a Multiport Ground-Water Sampling System in the 300 Area. PNL-6910, Pacific Northwest Laboratory, Richland, Washington.

Graham, M. J., G. V. Last, and K. R. Fecht. 1984. An Assessment of Aquifer Intercommunication with B Pond-Gable Mountain Pond at the Hanford Site. RHO-RE-ST-12P, Rockwell Hanford Operations, Richland, Washington.

Tal1man, A. M., K. R. Fecht, M. C. Marratt, and G. V. Last. 1979.

Geology of the Separations Area, Hanford Site, South-Central Washington. RHO-ST-23, Rockwe]l Hanford Operations, Richland, Washington. 

APPENDIX A 


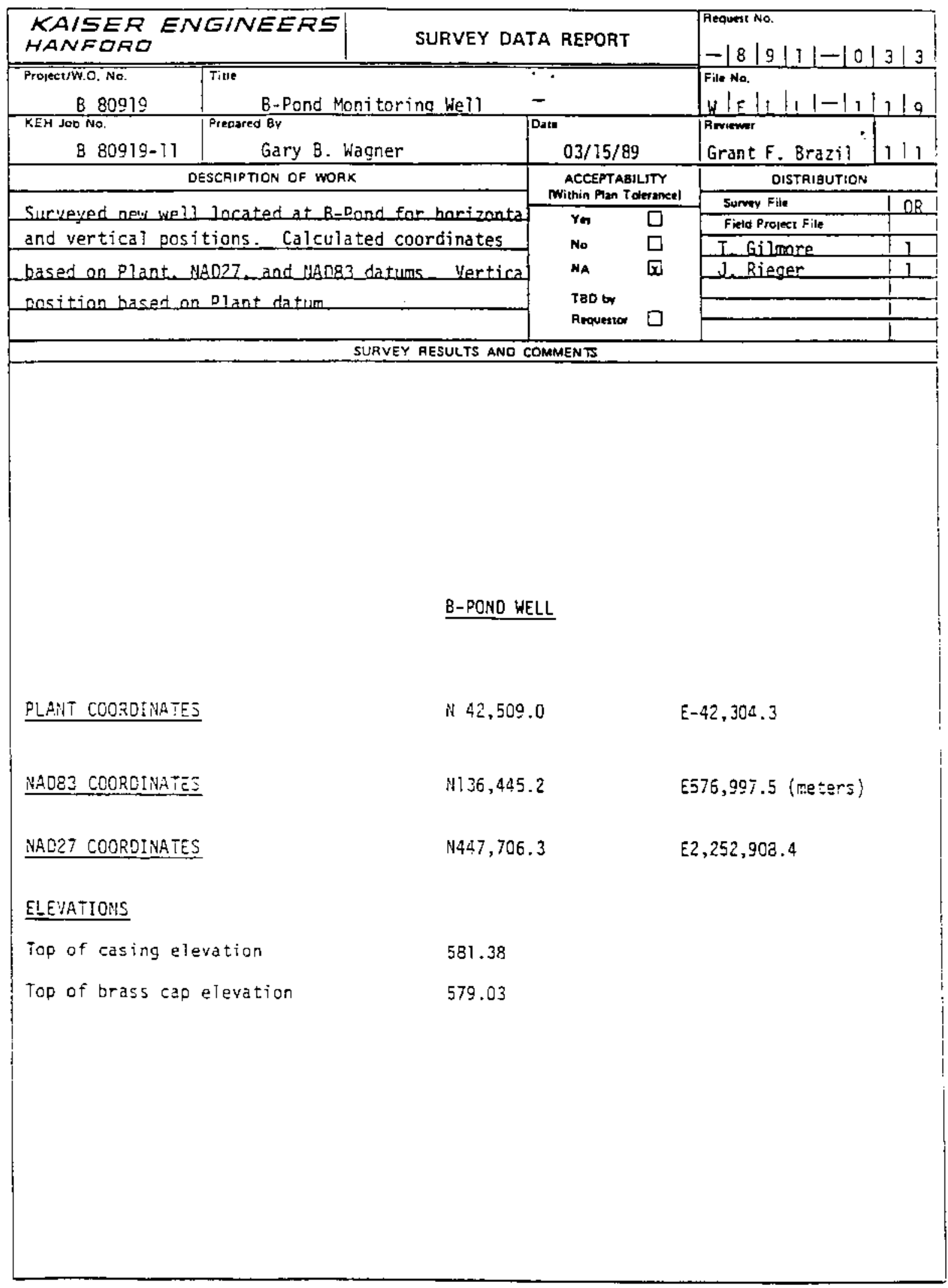

KEH.159.: (5.AA)

A. 1 


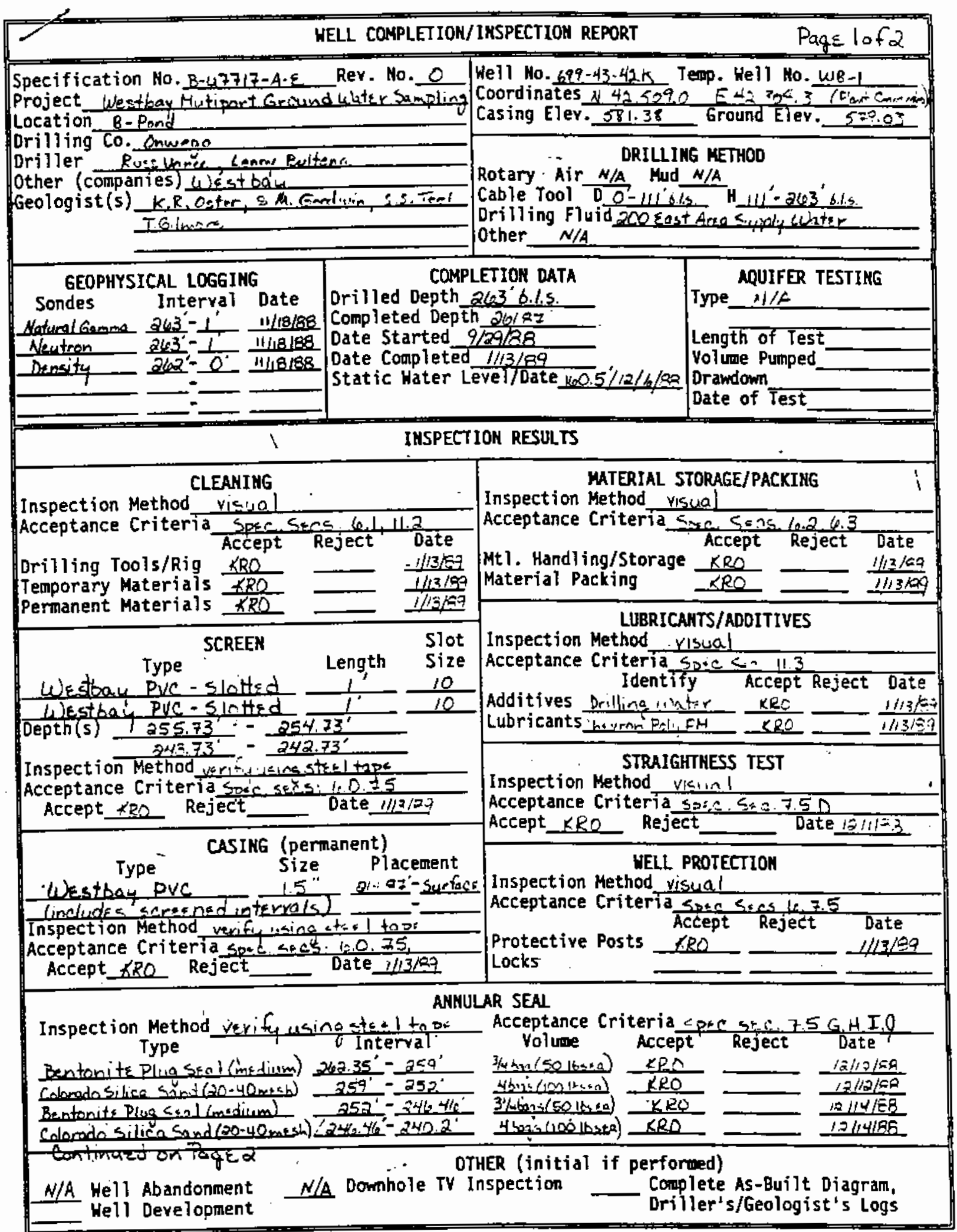

For all blanks wark $K / A$ if not applicable. 


\section{WELL COMPLETION/INSPECTION REPORT}

Page 2 of 2

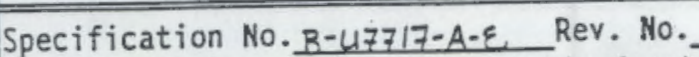
Project $\omega$ ) sestta, Multiport Growad Water Sampling Location $\mathrm{B}$-Pond

Drilling Co. Onuvea

Driller Russ Kanes Lisnna Bultena

Other (companies) Wrestbuc

Geologist (s) K.R.Qster, S.M. Sordwin, S.S.Tss I. Gilmone
Well No. $699.43-45 k$ Temp. Hell No. $\omega B-1$ Coordinates $N 425292=42304.3$ (Plent Condiniac) Casing Elev. 551.58 Ground Elev. $5=9.03$

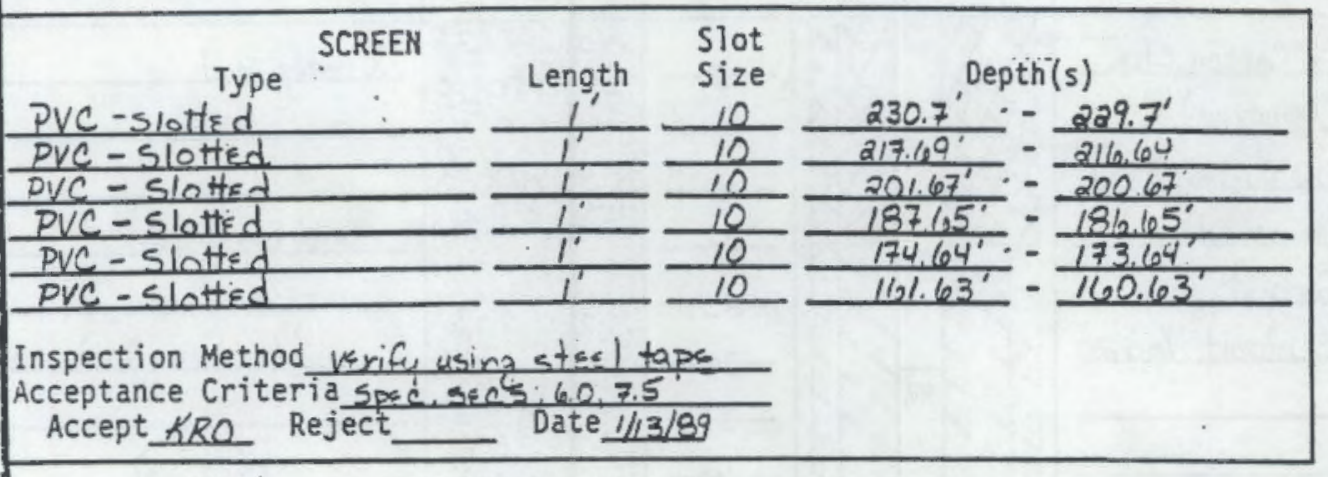

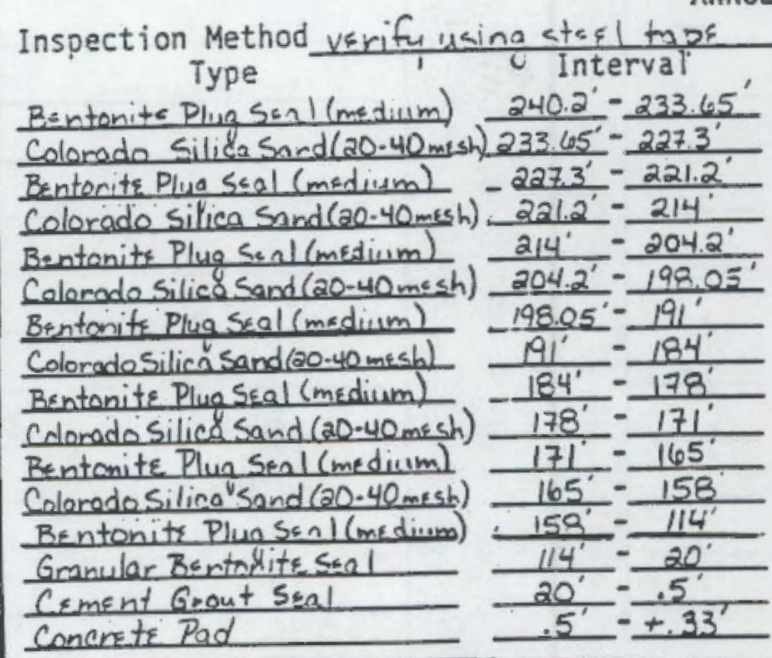

ANNULAR SEAL

Acceptance Criteria sptc SEC. 7.5 G,HII O Volume Accept Reject Date 5 tag $(50 / b a c a) \quad K R O-12 / 15 / 38$ 5 bras(100/bs5a) KRO $=\frac{12 / 1 / 16 / 82}{10 / 19 / 88}$

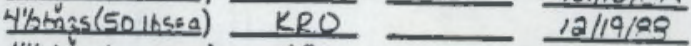

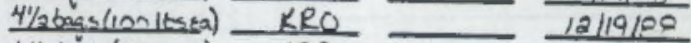
$6 \%$ hins(50/bsso) $-\mathrm{KRO} \longrightarrow \frac{12 / 9 / 28}{12 / 21 / 88}$ $5 \%$ angs $10016 s 50)-K R O=\frac{12121 / 89}{12121 / 85}$

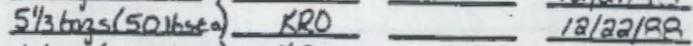
lebags (100/bs:a) KRO $4^{3 / 46 a s s(50 / 6 s 5 a) \quad K R O}-12 / 22 / 88$ $96005(100 / \mathrm{bssa}) \quad K R O-\frac{12 / 22 / 88}{12 / 27 / 88}$ $7 \mathrm{bags}$ (50/bsta) KRO $\longrightarrow \frac{K R O}{12 / 27 / 98}$ lobaas $\left(100 / \mathrm{bs}_{\mathrm{s}} \mathrm{a}\right) \mathrm{KRO} \longrightarrow 12 / 27 / 88$ 3Qhina (5n/bata) KRO $55 \mathrm{bans}(100 / \mathrm{hss})-\mathrm{KRO}-12 / 28 / 82$ 17bogs (a4/6x*a) - KRO - $1112 / 89$ $\underline{K R O}$ 


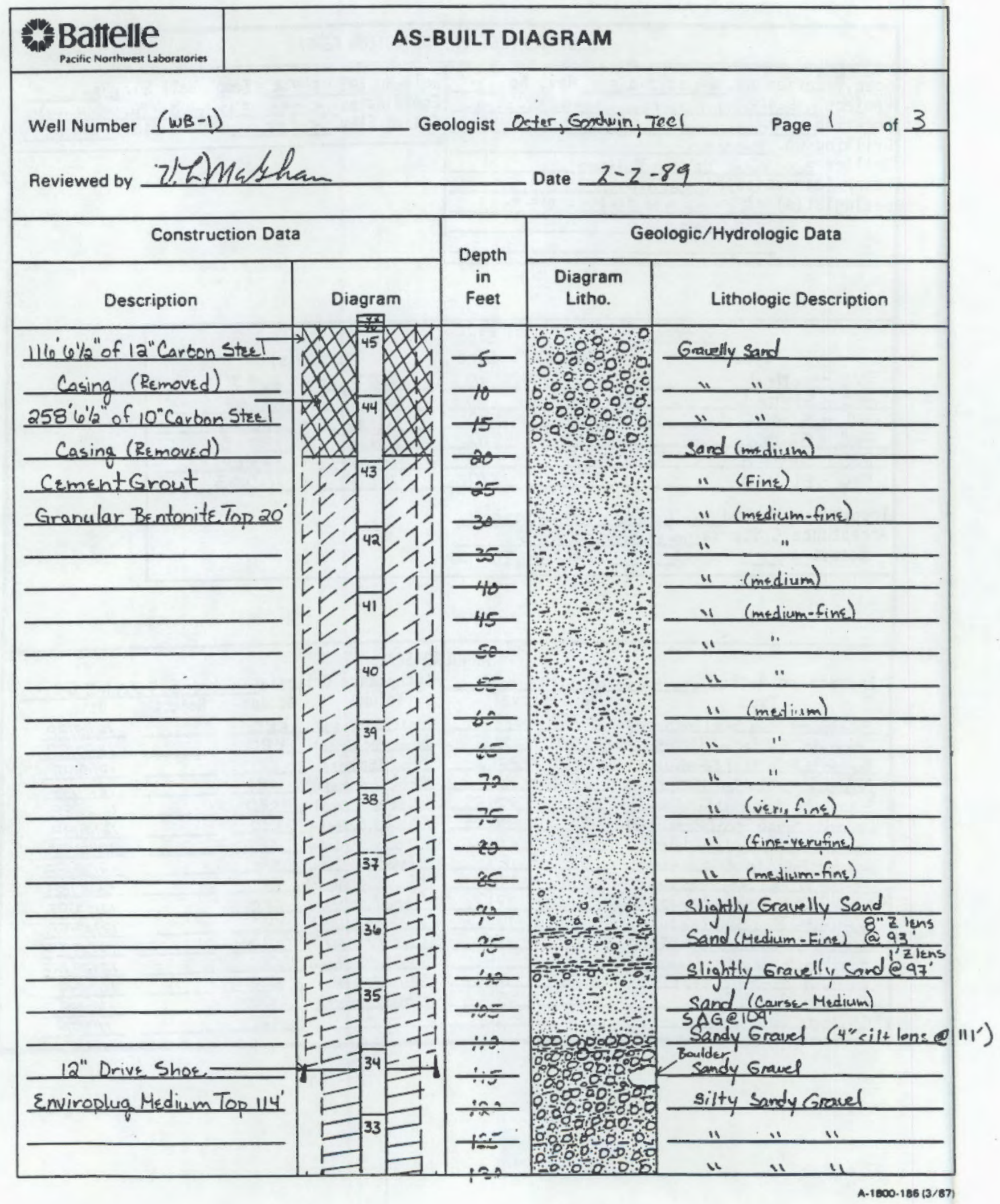




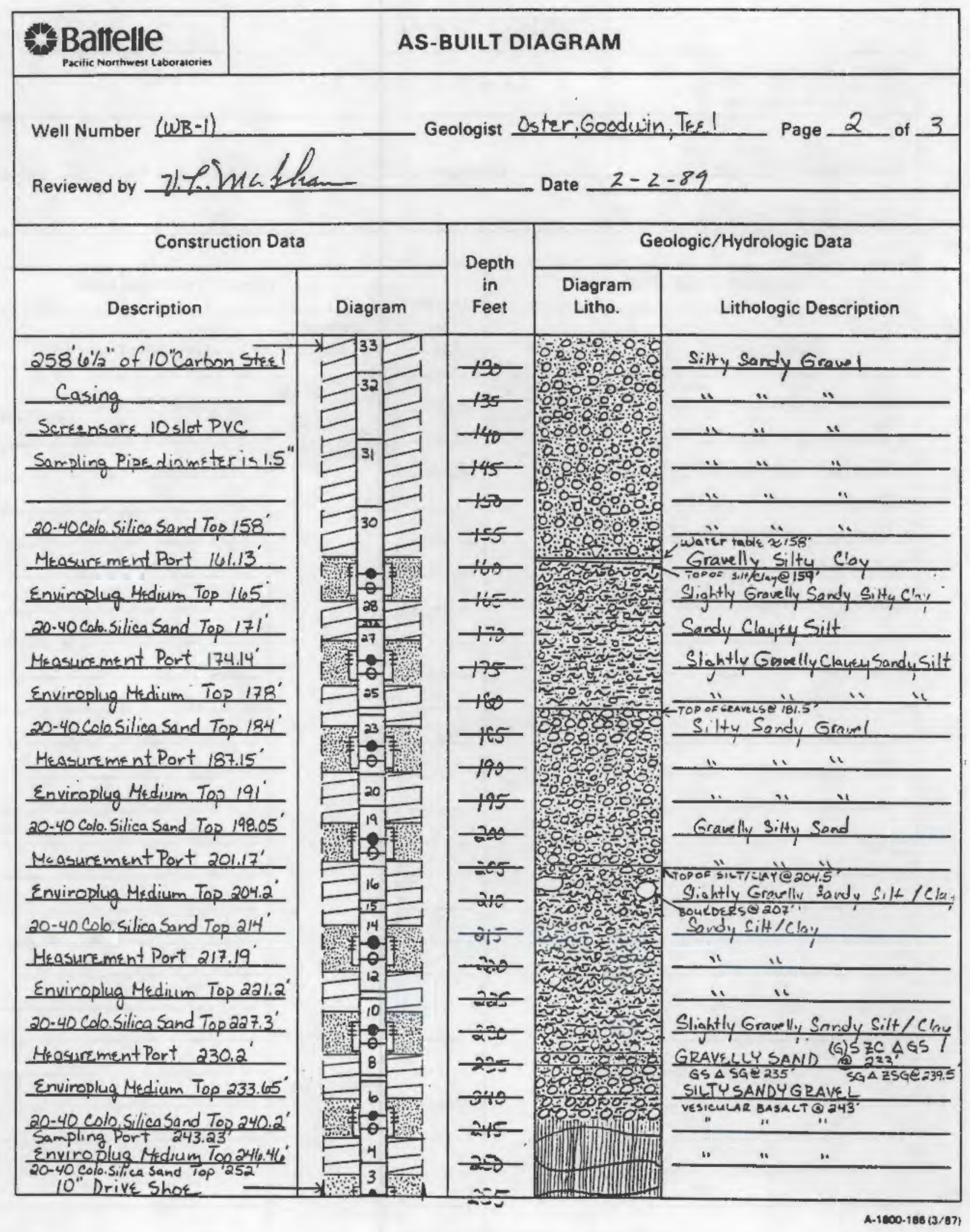




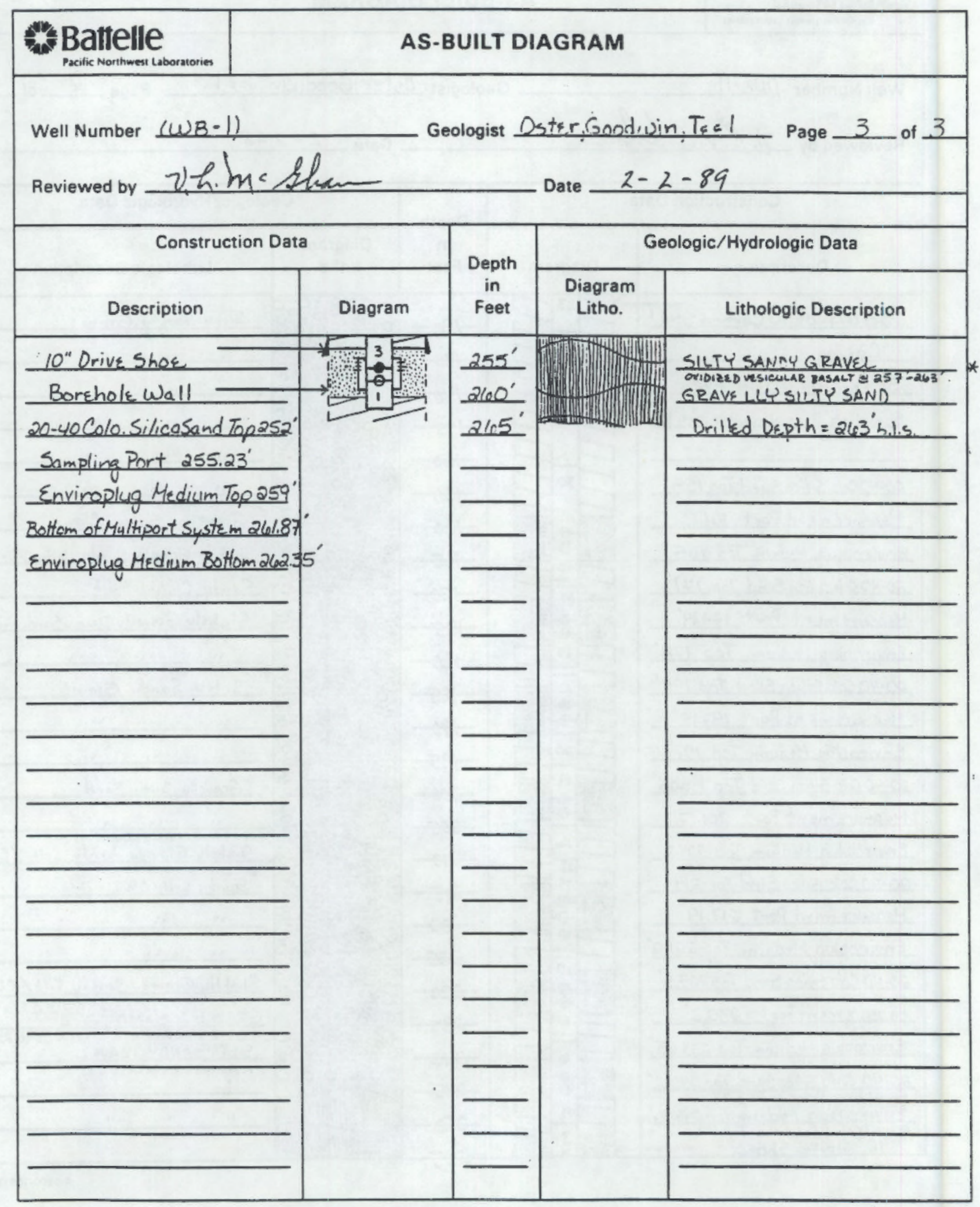

A. $1800-186(3 / 87)$ 
CASIMG LENGTH MEASUREMENT RECORD

Project: Battelle PML

Date: December 1, 1988

Project No.: $606-88$

Location: BPond

Drillhole No.: WB-1

Mominal B.0.H.: $163^{\prime}$

Casing Size/Type: 1.5" MP

Measured By: Kurt Seedhouse

\begin{tabular}{|c|c|c|c|c|c|c|}
\hline Section No. & Serial No. & Daseription & Now inal Longth, ft. & $\begin{array}{l}\text { Hossured Length, ft. } \\
\text { Top of Coupling }\end{array}$ & $\begin{array}{c}\text { Cunulative Length, ft. } \\
\text { Top of Coupling }\end{array}$ & Hagnatic Collars \\
\hline - & - & End Cap & 11 & 1' $4 / 16$ & .156 & -. \\
\hline 1 & 2117 & 5' Pumping Port & $\mathbf{s}^{\prime}$ & 5' & 5.18 & 4.16 \\
\hline 2 & 4962 & 2' Moasureaent Port & $2^{\prime}$ & 2' 1/16 & 7.16 & - \\
\hline 3 & - & 5' Coupling & 5' & s' 6 & 12.16 & - \\
\hline 4 & 2105 & 5' Pueping Port & $5^{\prime}$ & s' 0 & 17.16 & 16.16 \\
\hline 5 & 4963 & 2' Hasuresent Port & $2^{\prime}$ & 2' 2/16 & 19.17 & - \\
\hline 6 & - & 5' Coupling & 5' & S' $1 / 16$ & 24.10 & - \\
\hline 7 & - & 1' Coupling & 11 & 1' 2/18 & 25.19 & -- \\
\hline - & 2112 & 5' Pueping Port & b' & $5 \cdot 1 / 16$ & 30.19 & 29.16 \\
\hline 9 & 4060 & 2' Masaureaent Port & $2^{\prime}$ & 2' $1 / 16$ & 32.20 & $\cdots$ \\
\hline 10 & - & 5' Coupling & $5^{\prime}$ & S' $1 / 10$ & 37.20 & - \\
\hline 11 & -- & 1' Coupling & $1^{\prime}$ & $1^{\prime} \cdot 0$ & 38.20 & $\cdots$ \\
\hline 12 & 2113 & 5' Coupl ing Port & 51 & 50 & 43.20 & 42.20 \\
\hline 13 & 4061 & 2' Measureaent Port & $2^{\prime}$ & $2^{2} 1 / 16$ & 45.21 & $\cdots$ \\
\hline 14 & - & 5' Coupling & s' & $5^{\circ} 1 / 16$ & 50.21 & - \\
\hline 15 & - & 2' Coupling & $\mathbf{2}^{\prime}$ & $2^{\circ} 1 / 16$ & 52.22 & - \\
\hline 16 & - & 5' Coupling & ' & 5' $1 / 16$ & 57.22 & $\ldots$ \\
\hline 17 & 2114 & 2' Pusping Port & $\mathbf{2}^{\prime}$ & $2 \cdot 0$ & 50.22 & St. 22 \\
\hline 18 & 4050 & 2' Heasuresent Port & $2^{\prime}$. & 2' $1 / 18$ & 61.23 & $\cdots$ \\
\hline 19 & $\ldots$ & 5' Coupling & 5' & 5' $1 / 16$ & 6.23 & -- \\
\hline 26 & - & 5' Coupling & s' & 5' $1 / 16$ & 71.24 & -- \\
\hline 21 & 2103 & 2' Puaping Port & $2^{\prime}$ & 2' $1 / 18$ & 73.24 & 72.24 \\
\hline 22 & 4059 & 2' Unasurceent Port & '? & 2' $1 / 18$ & 75.25 & - \\
\hline 23 & - & 5' Coupling & $6^{\prime}$ & 5' $1 / 16$ & 0.25 & - \\
\hline 24 & - & 1' Coupling & 11 & 1' $2 / 16$ & 11.28 & \\
\hline 25 & 2106 & 5' Pusping Port & 61 & 50 & 68.26 & 85.26 \\
\hline
\end{tabular}


CASING LEMGTH MEASUREMENT RECORD

Project: Battelle PNL

Location: BPond

Casing Size/Type: $1.5^{\prime \prime}$ MP

\begin{tabular}{|c|c|c|c|c|c|c|}
\hline Section Mo. & Serial to. & Deceription & Mowinal Length, ft. & $\begin{array}{l}\text { Heasured Lempth, ft. } \\
\text { Top of Coupling }\end{array}$ & $\begin{array}{c}\text { Cuevilative Length, ft. } \\
\text { Top of Coupling }\end{array}$ & Magnetic Collars \\
\hline 20 & 4057 & 2' Pumping Port & '' & $2 \cdot 0$ & es. & -. \\
\hline 27 & - & 5' Coupling, 1' Coup. & s' & $\theta^{\prime} 1 / 16$ & 94.27 & - \\
\hline 27a & - & 1' Correction & - & - & - & -. \\
\hline 28 & 2104 & 5' Punping Port & 5 & $5 \cdot 0$ & 9.27 & 97.27 \\
\hline$x$ & 4054 & 2' Ueasurenent Port & $2^{\prime}$ & 2' $1 / 16$ & 101.27 & $\cdots$ \\
\hline 30 & -- & 10' Coupling & $\mathbf{w a}^{\prime}$ & $10^{\prime} 1 / 18$ & 111.28 & - \\
\hline 31 & - & 10' Coupling & $10^{\prime}$ & $10^{\prime} \mathrm{E}^{\circ}$ & 221.20 & $\cdots$ \\
\hline 32 & - & 10' Coupling & $10^{\prime}$ & $10 ' 1 / 16$ & 131.28 & - \\
\hline 33 & $\cdots$ & 10' Coupling & $10^{\prime}$ & $10^{\prime} 2 / 16$ & 141.30 & $\cdots$ \\
\hline 34 & - & 10' Coupling & $\boldsymbol{w}^{\prime}$ & $10^{\prime} 2 / 16$ & 151.31 & $\cdots$ \\
\hline 35 & $\cdots$ & 10' Coupling & $10^{\prime}$ & $10^{\prime} 1 / 16$ & 161.31 & - \\
\hline 36 & - & 10' Coupling & $10^{\prime}$ & $10 ' 0$ & 171.31 & - \\
\hline 37 & $\ldots$ & 10' Coupling & $10 '$ & $10 \cdot$ & 181.31 & -- \\
\hline 38 & - & 10' Coupling & $10^{\prime}$ & $10^{\prime} 0^{\circ}$ & 191.31 & - \\
\hline 39 & -- & 10' Coupling & $10^{\prime}$ & $10^{\prime}$ & 21.31 & -- \\
\hline 46 & - & 10' Coupling & $10^{\prime}$ & $10 \cdot 1 / 18$ & 211.32 & - \\
\hline 41 & $\cdots$ & 10' Coupling - & $10^{\prime}$ & $10 ' 1 / 18$ & 221.32 & $\cdots$ \\
\hline 42 & - & 10' Coupling & $10^{\prime}$ & $10^{\prime} \cdot 0^{\prime}$ & 201.32 & -- \\
\hline 43 & - & 10' Coupling & 10 & $10^{\prime} 1 / 16$ & 241.33 & - \\
\hline 44 & - & 10' Coupling & 10' & $10^{\prime} 0^{\circ}$ & 251.33 & $\cdots$ \\
\hline 45 & -. & 10' Coupling & 10 & $10^{\prime} 1 / 16$ & 201.33 & -- \\
\hline & & & & & & \\
\hline & & & & & & \\
\hline & & & & & & \\
\hline & & & & & & \\
\hline & & & & & & \\
\hline 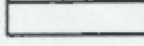 & . & 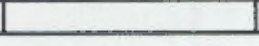 & & & & \\
\hline
\end{tabular}

Date: December 1, 1988

Drillhole Ho.: HB-1

Measured By: Kurt Seedhouse
Project Mo.: 606-88

Nominal B.O.H.: $163^{\prime}$ 


\section{DISTRIBUTION}

No. of

Copies

OFFSITE

2 DOE/Office of Scientific and Technical Information

\section{ONSITE}

2 DOE Richland Operations Office

E. A. Bracken

M. W. Tiernan

2 Westinghouse Hanford Company

K. R. Fecht

R. L. Jackson
No. of

Copies

26 Pacific Northwest Laboratory

R. W. Bryce

J. W. Falco

M. D. Freshley

R. H. Gray

T. J. Gilmore (5)

J. M. Hales

P. C. Hays

M. G. Hefty

G. V. Last

R. E. Lundgren

S. P. Luttrell

P. J. Mitchell

R. W. Nelson

R. L. Skaggs

R. M. Smith

R. E. Wildung

Publishing Coordination

Technical Report Files (5) 
